\title{
First report of PCR-based detection of Helicobacter species DNA in Camelus dromedarius in Egypt
}

\author{
Ahmed Youssef ${ }^{1}$ (D), Ahmed Afifi², Ayman Hamed ${ }^{3}$ and Mohamed Enany ${ }^{3}$
}

1. Department of Animal Hygiene and Zoonoses, Faculty of Veterinary Medicine, Suez Canal University, Ismailia 41522, Egypt; 2. Department of Microbiology (Bacteriology), Faculty of Veterinary Medicine, Suez Canal University, Ismailia 41522, Egypt; 3. Department of Biotechnology, Animal Health Research Institute, 7 Nady El Seid St., Dokki, Giza, Egypt. Corresponding author: Ahmed Youssef, e-mail: ayoussef22.com@gmail.com

Co-authors: AF: sondowth@yahoo.com, AH: Aymanmansour596@yahoo.com, ME: enanyeg@yahoo.com Received: 14-03-2020, Accepted: 10-07-2020, Published online: 17-09-2020

doi: www.doi.org/10.14202/vetworld.2020.1898-1901 How to cite this article: Youssef A, Afifi A, Hamed A, Enany M (2020) First report of PCR-based detection of Helicobacter species DNA in Camelus dromedarius in Egypt, Veterinary World, 13(9): 1898-1901.

\begin{abstract}
Background and Aim: Helicobacter species infections have epidemiological and zoonotic impacts, and different species of Helicobacter have been implicated in infecting humans and animals. The aim of this study was to investigate Helicobacter species infections in Camelus dromedarius.
\end{abstract}

Materials and Methods: Fecal samples were collected from 32 camels from 9 camel farms located at Ismailia Governorate, Egypt. The collected samples were investigated by bacteriological isolation and conventional polymerase chain reaction (PCR) assays targeting the $16 \mathrm{~S}$ ribosomal RNA gene.

Results: Although Helicobacter species could not be isolated from all the examined samples, Helicobacter DNA was detected in $2(22.22 \%)$ of the 9 camel farms. Of the 32 camel fecal samples examined, 4 (12.5\%) were positive for Helicobacter species as analyzed by the PCR assay.

Conclusion: To the best of our knowledge, this is the first report of PCR-based detection of Helicobacter species infections in C. dromedarius. Further epidemiological studies are required to clarify Helicobacter species infections in camels.

Keywords: Camelus dromedarius, Helicobacter, Non-pylori, polymerase chain reaction.

\section{Introduction}

Following the discovery of Helicobacter pylori in humans, Helicobacter species have been reported in both wild and domestic mammals having varying dietary habits, such as dogs, cats, mice, swine, cattle, and sheep [1,2]. Helicobacter species that infect animals are generally termed as Helicobacter-like organisms, and these organisms are known to have different morphological characteristics than those of H. pylori (Non-Helicobacter pylori species) that commonly infect humans $[3,4]$. It is difficult to distinguish these non- $H$. pylori species from each other through histopathological examinations of gastric tissue sections by light microscopy [1]. Both $H$. pylori and non- $H$. pylori species are known to infect animals with a zoonotic mode of transmission to humans [3-5]. However, there is a lack of information regarding the role of these species in the pathogenesis of gastric diseases in animals [6].

There are various detection methods for the diagnosis of Helicobacter species, including invasive and

Copyright: Youssef, et al. Open Access. This article is distributed under the terms of the Creative Commons Attribution 4.0 International License (http://creativecommons.org/licenses/ by/4.0/), which permits unrestricted use, distribution, and reproduction in any medium, provided you give appropriate credit to the original author(s) and the source, provide a link to the Creative Commons license, and indicate if changes were made. The Creative Commons Public Domain Dedication waiver (http:// creativecommons.org/publicdomain/zero/1.0/) applies to the data made available in this article, unless otherwise stated. non-invasive techniques. Bacteriological isolation of Helicobacter species encompasses several difficulties, and moreover, their isolation requires well-equipped microbiological laboratories and well-trained researchers; moreover, some Helicobacter species are reported to be unculturable [7]. Nonetheless, molecular detection of the DNA of Helicobacter spp. in clinical samples by polymerase chain reaction (PCR) assays provide a valuable tool for the identification of Helicobacter spp. with high sensitivity and specificity rates $[7,8]$. In this regard, the identification of Helicobacter bacteria, particularly unculturable species, using PCR assays based on the $16 \mathrm{~S}$ ribosomal DNA gene remains the most frequently used method of detection [9].

Camels are implicated to be reservoirs of several infectious diseases, including parasitic, bacterial, and viral diseases. Some of these infectious diseases of camels are zoonotic and pose public health concerns. However, there remains a lack of information regarding Helicobacter infections in camels. Therefore, this study was conducted to detect Helicobacter spp. infections in Camelus dromedarius.

\section{Materials and Methods}

\section{Ethical approval}

This study was approved by the Research Ethics Committee of the Suez Canal University.

\section{Sample collection}

A total of 32 fecal samples were collected from 9 camel farms located in Ismailia Governorate, 
Egypt, from January to March 2019. All samples were collected from apparently healthy animals. The geographic distribution of the farms was as follows: Ismailia center $(n=3)$, Al Tal Al Kabir $(n=1)$, Fayid $(\mathrm{n}=1)$, and $\mathrm{Al}$ Qantarah $(\mathrm{n}=4)$. In total, $100 \mathrm{~g}$ of fresh fecal sample was collected in sterile containers. The fecal specimens were transported on ice and processed within $2 \mathrm{~h}$ for culture to avoid reducing the viability of the organisms due to exposure to atmospheric oxygen. The samples that were not cultured on solid media within $2 \mathrm{~h}$ were enriched in a transport medium to maintain the viability of bacteria. Brain-heart infusion (BHI) broth (Oxoid, CM 0385B, UK) supplemented with $5 \%$ horse serum or phosphate-buffered saline at a dilution of $20 \% \mathrm{w} / \mathrm{v}$ was used as a transport medium to prevent dryness. The suspension of the diluted sample was sieved through a $250 \mu \mathrm{m}$ strainer before plating onto selective media.

\section{Bacteriological isolation of Helicobacter species}

One milliliter of each diluted sample was inoculated into each of two sterile test tubes containing $9 \mathrm{~mL}$ of BHI broth supplemented with $5 \%$ sterile horse serum. The first tube was supplemented with non- $H$. pylori selective supplement (Skirrow's medium), whereas the second one was supplemented with $H$. pylori selective supplement (DENT, OXOID, code SR0147, UK). The inoculated test tubes were incubated at $37^{\circ} \mathrm{C}$ under microaerobic conditions using an activated gas generating kit $\left(5 \% \mathrm{H}_{2}, 5 \% \mathrm{CO}_{2}\right.$, $5 \% \mathrm{O}_{2}$, and $85 \% \mathrm{~N}_{2}$ ). The cultures were maintained for $96 \mathrm{~h}$ and observed daily. The incubated broth was streaked by plating on each of (1) Columbia agar (TM MEDIA, TMH 116, India) supplemented with 5\% defibrinated sheep blood and Helicobacter selective supplement (Skirrow's medium) (HIMEDIA, code FD 008, India) and (2) Columbia agar supplemented with $5 \%$ defibrinated sheep blood and H. pylori selective supplement (DENT). The Columbia agar media were also supplemented with Vitamino Growth Supplement (HiMedia, code FD025, India) according to the manufacturer's instructions. The streaked plates were incubated at $37^{\circ} \mathrm{C}$ for $3-5$ days under microaerobic conditions, and any suspected Helicobacter colonies were examined for colonial morphology. The plates were not discarded until 12 days.

\section{DNA extraction from fecal samples}

Bacterial DNA was extracted from the fecal samples using the QIAamp DNA Stool Mini Kit (Qiagen, GERMANY) according to the manufacturer's instructions.

\section{PCR assays of Helicobacter species}

PCR assays were performed using the EmeraldAmp GT PCR Master Mix Kit (Takara Bio., Japan). The oligonucleotide sequences (Metabion, Germany) of the primers targeting the 16S rRNA of Helicobacter species were as follows: Forward primer 5'-AAC GAT GAA GCT TCT AGC TTG CTA-3' and reverse primer 5'-GTG CTT ATT CGT GAG ATA CCG
TCA T-3' for the amplification of $398 \mathrm{bp}$ as described previously [10]. Each $25 \mu \mathrm{L}$ of the PCR mixture consisted of $12.5 \mu \mathrm{L}$ of $2 \times$ master mix, $1 \mu \mathrm{L}$ of each primer (20 pmol), $5 \mu \mathrm{L}$ of DNA template, and $5.5 \mu \mathrm{L}$ PCRgrade water. The cycling conditions consisted of one cycle of initial denaturation at $94^{\circ} \mathrm{C}$ for $5 \mathrm{~min}$, followed by 35 cycles of denaturation at $94^{\circ} \mathrm{C}$ for $30 \mathrm{~s}$, annealing at $54^{\circ} \mathrm{C}$ for $40 \mathrm{~s}$, and extension at $72^{\circ} \mathrm{C}$ for $30 \mathrm{~s}$. The final extension consisted of one cycle at $72^{\circ} \mathrm{C}$ for $7 \mathrm{~min}$. The PCR products were electrophoresed after loading onto $1 \%$ agarose gel using a final concentration of $0.1-0.5 \mu \mathrm{g} / \mathrm{mL}$ ethidium bromide solution. The DNA molecular weight marker was used in the gel electrophoresis using a 100 bp ladder (Gel Pilot QIAGEN, USA). The gel was photographed by a gel documentation system (Alpha Innotech, CA, USA), and the data were analyzed using computer software.

\section{Results}

Bacteriological isolation of Helicobacter species in the fecal samples of camels

The results showed that $H$. pylori and non-H. pylori species could not be isolated from all fecal samples using selective media.

\section{Prevalence of Helicobacter spp. in the fecal samples of camels by PCR}

Helicobacter DNA was detected in the fecal samples of camels from $2(22.22 \%)$ of the 9 camel farms. Of the 32 examined fecal samples of camels, 4 (12.5\%) were positive for Helicobacter species. The farms that showed positivity included one farm from Ismailia center in which $1(50 \%)$ of 2 camels' samples was positive and another farm located in Qantarah center in which $3(75 \%)$ of 4 camels' samples were positive for Helicobacter species (Table-1 and Figure-1).

\section{Discussion}

Non- $H$. pylori species can infect both humans and animals, and their probable transmission between humans and animals might serve as a reservoir for the transmission of pathogenic microorganisms to

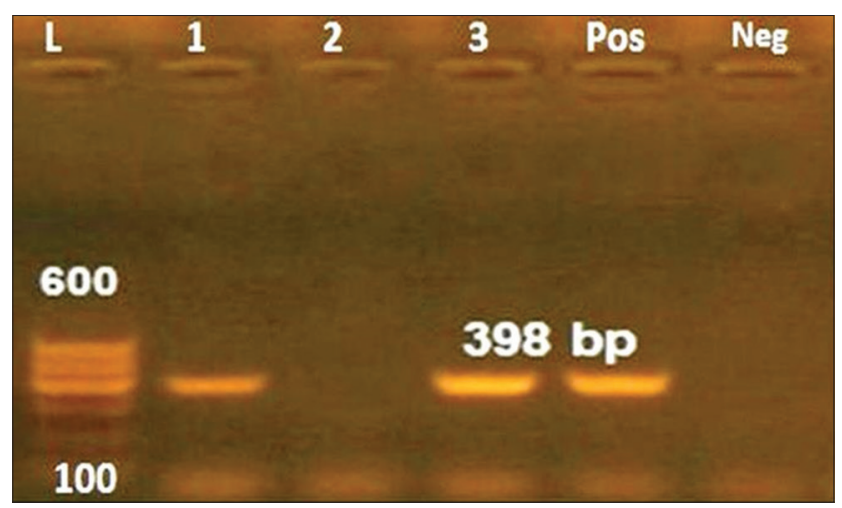

Figure-1: Agarose gel electrophoresis of polymerase chain reaction performed on Helicobacter spp. strains for the detection of $16 \mathrm{~S}$ rRNA gene amplification product with a size of $398 \mathrm{bp}$. Lanes 1, 3 were positive; lane 2 was negative; $L$ indicated the DNA ladder (100 bp $600 \mathrm{bp}$ ) and Pos showed the control positive ( $H$. pylori DNA) and Neg showed the control negative. 
Table-1: The prevalence of Helicobacter spp. infection among examined camels.

\begin{tabular}{lcccc}
\hline No. of farms & $\begin{array}{c}\text { Number of camels } \\
\text { examined }\end{array}$ & $\begin{array}{c}\text { Number of positive } \\
\text { camels } /(\mathbf{\%})\end{array}$ & Farms locations & $\begin{array}{c}\text { Positive } \\
\text { farms/(\%) }\end{array}$ \\
\hline 1 & 3 & 0 & Ismailia & Negative \\
2 & 2 & $1(50 \%)$ & Ismailia & Positive \\
3 & 7 & 0 & Ismailia & Negative \\
4 & 5 & 0 & Qantarah & Negative \\
5 & 4 & $3(75 \%)$ & Qantarah & Positive \\
6 & 2 & 0 & Qantarah & Negative \\
7 & 5 & 0 & Qantarah & Negative \\
8 & 3 & 0 & Al Tal El Kabir & Negative \\
9 & 1 & 0 & Fayid & Negative \\
Total $=9$ & 32 & $4(12.5 \%)$ & & $2(22.22 \%)$ \\
\hline
\end{tabular}

human contacts [11]. In vitro cultivation of the gastric non- $H$. pylori species organisms is extremely difficult and cannot be exclusively used for diagnostic purposes, which necessitates different techniques for the diagnosis of Helicobacter infections [7-12]. In the present study, using PCR, we identified the presence of Helicobacter spp. in the fecal samples of camels. The failure of isolation of Helicobacter species in camels that were detected by PCR indicated that Helicobacter infections in camels were associated with infection by non- $H$. pylori species other than the culturable species. Furthermore, the detection of Helicobacter spp. DNA in two camel farms from different localities indicated the spread of infection among the camels.

It has been reported that humans can be infected by different Helicobacter spp., the majority of which are common or potentially pathogenic, and most of which are probably zoonotic infections transmitted due to contact with animals [4]. Contact with cats, dogs, cattle, and pigs has been associated with Helicobacter infections in humans $[4,13]$. The camels examined in this study were reared in households in close contact with humans and other animals. Therefore, there is a possibility that camels could be one of the reservoirs of human infections by Helicobacter species. Several previous studies have supported the possibility of zoonotic infections of Helicobacter species. In the previous studies, $H$. pylori was isolated from sheep milk, based on which its zoonotic transmission from sheep was proposed [5,14]. Flahou et al. [15] found that Helicobacter suis colonized the stomach of asymptomatic rhesus and cynomolgus monkeys and suggested that $H$. suis infections in pigs possibly originated from nonhuman primates as a host jump from macaques to pigs that occurred thousands of years ago and that pig domestication has had a significant impact on the spread of $H$. suis in the pig population, from where this pathogen occasionally infects humans.

Our results supported by previous studies for detection of $H$. pylori DNA in camel's milk in Iran by prevalence of (23.4\%) [16], (13.33\%) [17] and $(5 \%)$ [18]. However, these studies focused on the detection of $H$. pylori species in milk of camels, whereas our study included the detection of Helicobacter spp. in the feces of camels.

\section{Conclusion}

To the best of our knowledge, this is the first report of the detection of Helicobacter species infections in C. dromedarius. Further research is needed to clarify Helicobacter species infections in camels in terms of the epidemiological features and genome characterization.

\section{Authors' Contributions}

AY, AA and AH: Designed the study, collected the data, performed the laboratory work (PCR) and drafted the manuscript. AY and ME: Shared in the conception of the research idea, planned laboratory work, helped in the manuscript preparation. All authors discussed the results and commented on the manuscript and contributed to the final version of the manuscript. All authors have read and approved the final manuscript.

\section{Acknowledgments}

The authors are thankful to the Central Laboratory and the Laboratory of Zoonoses, Faculty of Veterinary Medicine, Suez Canal University, for supplying materials during this work. The authors are also thankful to the Department of Biotechnology and Food Hygiene, Animal Health Institute, Dokki, Egypt, for providing the required facilities of PCR. The authors did not receive any funds for this study.

\section{Competing Interests}

The authors declare that they have no competing interests.

\section{Publisher's Note}

Veterinary World remains neutral with regard to jurisdictional claims in published institutional affiliation.

\section{References}

1. Buczolits, S., Hirt, R., Rosengarten, R. and Busse, H.J. (2003) PCR-based genetic evidence for occurrence of Helicobacter pylori and novel Helicobacter species in the canine gastric mucosa. Vet. Microbiol., 95(4): 259-70.

2. Solnick, J.V. (2003) Clinical significance of Helicobacter species other than Helicobacter pylori. Clin. Infect. Dis., 36(3): 349-354.

3. Blaecher, C., Bauwens, E., Tay, A., Peters, F., Dobbs, S., 
Dobbs, J., Charlett, A., Ducatelle, R., Haesebrouck, F. and Smet, A. (2017) A novel isolation protocol and probe-based RT-PCR for diagnosis of gastric infections with the zoonotic pathogen Helicobacter suis. Helicobacter, 22(3): 12369.

4. Mladenova-Hristova, I., Grekova, O. and Patel, A. (2017) Zoonotic potential of Helicobacter spp. J. Microbiol. Immunol. Infect., 50(3): 265-269.

5. Sabry, M.A., Abdel-Moein, K.A. and Seleem, A. (2016) Evidence of zoonotic transmission of Helicobacter canis between sheep and human contacts. Vector Borne Zoonotic Dis., 16(10): 650-653.

6. Amorim, I., Smet, A., Alves, O., Teixeira, S., Saraiva, A.L., Taulescu, M., Reis, C., Haesebrouck, F. and Gärtner, F. (2015) Presence and significance of Helicobacter spp. in the gastric mucosa of Portuguese dogs. Gut Pathog.,7(1): 12.

7. Makristathis, A., Hirschl, A.M., Megraud, F. and Bessede, E. (2019) Review: Diagnosis of Helicobacter pylori infection. Helicobacter, 24(1): e12641.

8. Patel, A., Shah, N. and Prajapati, J.B. (2014) Clinical application of probiotics in the treatment of Helicobacter pylori infection-a brief review. J. Microbiol. Immunol. Infect., 47(5): 429-437.

9. Dewhirst, F.E., Shen, Z., Scimeca, M.S., Stokes, L.N., Boumenna, T., Chen, T., Paster, B.J. and Fox, J.G. (2005) Discordant $16 \mathrm{~S}$ and 23S rRNA gene phylogenies for the genus Helicobacter: Implications for phylogenetic inference and systematics. J. Bacteriol.,187(17): 6106-6118.

10. Germani, Y., Dauga, C., Duval, P., Huerre, M., Levy, M., Pialoux, G., Sansonetti, P. and Grimont, P.A. (1997) Strategy for the detection of Helicobacter species by amplification of $16 \mathrm{~S}$ rRNA genes and identification of $H$. felis in a human gastric biopsy. Res. Microbiol., 148(4): 315-326.

11. De Witte, C., Lemmens, C., Flahou, B., De Laender, P., Bouts, T., Vercammen, F., Ducatelle, R., Smet, A. and Haesebrouck, F. (2018) Presence of Helicobacter and Campylobacter species in faecal samples from zoo mammals. Vet. Microbiol., 219: 49-52.

12. Jalava, K., On, S.L., Vandamme, P.A., Happonen, I., Sukura, A. and Hänninen, M.L. (1998) Isolation and identification of Helicobacter spp. from canine and feline gastric mucosa. Appl. Environ. Microbiol., 64(10): 3998-4006.

13. Elhariri, M., Elhelw, R., Hamza, D. and El-Mahallawy, H.S. (2017) Serologic evidence and risk factors for Helicobacter pylori infection in animals and humans. J. Infect. Dev. Ctries, 11(5): 414-419.

14. Dore, M.P., Sepulveda, A.R., Osato, M.S., Realdi, G. and Graham, D.Y. (1999) Helicobacter pylori in sheep milk. Lancet, 354(9173): 132.

15. Flahou, B., Rossi, M., Bakker, J., Langermans, J.A., Heuvelman, E., Solnick, J.V., Martin, M.E., O'Rourke, J., Ngoan, L.D., Hoa, N.X., Nakamura, M., Øverby, A., Matsui, H., Ota, H., Matsumoto, T., Foss, D.L., Kopta, L.A., Omotosho, O., Franciosini, M.P., Proietti, P.C., Guo, A., Liu, H., Borilova, G., Bracarense, A.P., Lindén, S.K., De Bruyckere, S., Zhang, G., De Witte, C., Smet, A., Pasmans, F., Ducatelle, R., Corander, J. and Haesebrouck, F. (2018) Evidence for a primate origin of zoonotic Helicobacter suis colonizing domesticated pigs. ISME J., 12(1): 77-86.

16. Rahimi, E. and Kheirabadi, E.K. (2012) Detection of Helicobacter pylori in bovine, buffalo, camel, ovine, and caprine milk in Iran. Foodborne Pathog. Dis., 9(5): 453-456.

17. Talaei, R., Souod, N., Momtaz, H. and Dabiri, H. (2015) Milk of livestock as a possible transmission route of Helicobacter pylori infection. Gastroenterol. Hepatol. Bed. Bench., 8(Suppl 1): S30-S36.

18. Ranjbar, R., Farsani, F.Y. and Dehkordi, F.S. (2018) Phenotypic analysis of antibiotic resistance and genotypic study of the vacA, cagA, iceA, oipA and babA genotypes of the Helicobacter pylori strains isolated from raw milk. Antimicrob. Resist. Infect. Control, 7: 115. 